\title{
Analisis Komparasi Sistem Pendidikan Indonesia dan Finlandia
}

\author{
Maulana Amirul Adha \\ Universitas Negeri Malang \\ amirulmaulana1013@gmail.com \\ Saverinus Gordisona \\ Universitas Negeri Malang \\ sonysaveriand@gmail.com \\ Nurul Ulfatin \\ Universitas Negeri Malang \\ nurul.ulfatin.fip@um.ac.id \\ Achmad Supriyanto \\ Universitas Negeri Malang \\ a.supriyanto.fip.@um.ac.id
}

\begin{abstract}
Education currently occupies a very important position in human development. The quality of the Finnish educational system is interesting to study because its success has been recognized worldwide. This study provides an overview of the comparison of the education systems of the countries of Indonesia and Finnish. The method used in this study is literature study. The results of the study show several differences, (1) Indonesia's educational system is colored by many competitions while Finnish puts forward the principle of equality; (2) Indonesia has a system of failing a grade and student ranking, Finnish has'nt failing a grade and ranking system; (3) Indonesia load learning every week +/- 40 hours, Finnish lessons +/- 30 hours per week; (4) Indonesia learns a lot in class, Finnish puts forward problem solving methods; (5) Indonesia assignments almost become a routine agenda every face to face, Finnish does not burden students with a lot of tasks, (6) Indonesia minimum teacher qualifications D4, Finnish minimum teacher qualifications S2 (Master), (7) Indonesian qualifications students enter basic education for at least 6 years $(5.5$ years accompanied by written recommendations from professional psychologists), Finnish qualifications for students entering basic education for at least 7 years.
\end{abstract}

Keywords: Educational System, Comparative Analysis, Indonesia, Finnish, Educational Quality

Abstrak : Di era milenial seperti saat ini pendidikan menempati posisi yang sangat penting dalam perkembangan manusia. Kualitas sistem pendidikan Finlandia menarik menjadi kajian karena keberhasilannya telah diakui dunia. Penelitian ini memberikan gambaran mengenai perbandingan sistem pendidikan negara Indonesia dan Finlandia. Kajian kepustakaan adalah metode yang digunakan dalam penelitian ini. Hasil telaah menunjukkan beberapa perbedaan yakni (1) Indonesia sistem pendidikan diwarnai banyak kompetisi sedangkan Finlandia mengedepankan prinsip kesetaraan; (2) Indonesia ada sistem tinggal kelas dan perangkingan siswa, Finlandia tidak ada sistem tinggal kelas dan perangkingan; (3) Indonesia beban belajar setiap minggu $+/$ - 40 jam, Finlandia jam pelajaran $+/-30$ jam per minggu; (4) Indonesia pembelajaran banyak dikelas, Finlandia mengedepankan metode problem solving; (5) Indonesia pemberian tugas hampir menjadi agenda rutin setiap tatap muka, Finlandia tidak membebani peserta didik dengan tugas yang banyak, (6) Indonesia kualifikasi Guru minimal D4, Finlandia kualifikasi guru minimal S2 (Master), (7) Indonesia kualifikasi peserta didik memasuki pendidikan dasar minimal 6 tahun $(5,5$ tahun disertai rekomendasi tertulis

TADBIR : Jurnal Studi Manajemen Pendidikan vol. 3, no. 2, November 2019 IAIN Curup - Bengkulu | p-ISSN 2580-3581; e-ISSN 2580-5037 
dari psikolog profesional), Finlandia kualifikasi peserta didik memasuki pendidikan dasar minimal 7 tahun.

Kata Kunci: Sistem Pendidikan, Analisis Komparasi, Indonesia, Finlandia, Mutu Pendidikan

\section{Pendahuluan}

Indonesia pada masa sekarang ini dihadapkan dengan berbagai macam permasalahan baik yang berasal dari luar maupun dari dalam negara itu sendiri. Permasalahan tersebut terjadi sebagai akibat dari banyaknya perubahan perubahan yang mendunia, contohnya adalah kemajuan IPTEK, pergeseran nilai sosial dan kebudayaan pada masyarakat. Pendidikan sebagai lembaga yang dinamis juga merasakan pengaruh atas perubahan tersebut. Perubahan budaya yang membawa dampak terhadap kemajuan dan perkembangan pendidikan. Pendidikan dibutuhkan manusia untuk berkembang. Manusia yang berkualitas dan mampu bersaing dapat diciptakan melalui pendidikan yang baik. Kualitas pembelajaran yang masih jauh dari di bawah kata sempurna menjadikan usaha pembangunan sumber daya manusia berjalan dengan lambat (Charron et al., 2013). Kualitas pendidikan di Indonesia diharapkan mampu menjawab tuntutan perkembangan zaman.

Di era milenial seperti saat ini pendidikan menempati posisi yang sangat penting dalam perkembangan manusia (Sarica \& Cavus, 2009). Tuntutan pekerjaan, hobi, bahkan gaya hidup mendorong sebagian besar orang untuk selalu belajar dalam setiap kondisi kehidupannya. Negara Republik Indonesia memiliki sebuah sistem pendidikan yang telah dikembangkan sejak tahun 1947 melalui kurikulum yang pertama kali diterapkan yaitu rencana pelajaran 1947. Perkembangan zaman memberikan peluang bagi para pakar pendikan untuk menyusun sebuah sistem pendidikan yang sesuai dan dapat menjiwai semangat Pancasila sebagai dasar negara Indonesia. Membangun sebuah sistem pendidikan tentunya membutuhkan banyak pertimbangan dari berbagai aspek dan komponen yang terkandung dalam masyarakat. Hubungan yang terjalin dalam setiap komponen tersebut didasarkan pada sebuah tujuan yang telah direncanakan.

Studi komparasi adalah disiplin ilmu yang mempelajari sistem-sistem pendidikan baik dalam satu negara, maupun antar negara (Pfeffer, 2015; Reynolds et al., 2015). Aneka inovasi pendidikan baik melalui menggali sumbersumber kreatif dari dalam negeri maupun melalui analisis komparasi pendidikan negara lain yang dianggap berhasil dalam mengembangkan kualitas pendidikan. Melalui analisis komparasi pendidikan, kita dapat mengetahui bagaimana negara lain merencanakan pengembangan dan peningkatan sistem pendidikannya yang dapat ditiru, maka pendidikan komparatif berusaha memberikan kontribusi dan rekomendasi kepada pengambilan kebijakan dalam rangka membangun dan memajukan sistem pendidikan. 
Finlandia dalam beberapa dekade terakhir mentransformasi sistem pendidikan di negaranya menjadi yang terbaik diseluruh dunia. Hal tersebut mengacu pada hasil tes yang diselenggarakan OECD (Organization for Economic Cooperation \& Development) pada tahun 2015 yakni tes PISA (Programme for International Student Assessment) negara Finlandia ada di jajaran negara teratas dengan kualitas pendidikan terbaik dilihat dari science, reading, dan mathematics. Pada tes ini Indonesia berada pada jajaran negara dengan kualitas pendidikan terendah (OECD, 2015).

Melihat kondisi diatas menarik untuk dikaji karena, merujuk pada pernyataan Anies Baswedan mantan menteri pendidikan dan kebudayaan negara Indonesia (Liputan6.Com , 2014) pendidikan di negara Finlandia dalam 30 tahun terakhir mengalami kemajuan yang sangat pesat, padahal pada tahun 1980-an keadaan pendidikan di Finlandia tidak lebih baik dari Indonesia. Menurut Anies Baswedan di balik berkembangnya pendidikan di Finlandia karena negara itu menganut apa yang telah ditulis dan diajarkan oleh Ki Hadjar Dewantara. Ironisnya berdasarkan pernyataan tersebut Indonesia saat ini jauh tertinggal dalam hal pendidikan, yang notabene Ki Hajar Dewantara merupakan bapak Pendidikan Indonesia, tetapi Pendidikan di Finlandia dapat berkembang dengan sangat pesat.

Perjalanan panjang sejarah sistem Pendidikan Indonesia telah dibuktikan dengan terjadinya pergantian kurikulum Pendidikan Nasional. Dalam rentang waktu 71 tahun semenjak tahun 1947 Indonesia terhitung 10 kali melakukan pergantian. Pergantian ini tentunya bertujuan untuk meningkatkan kualitas Pendidikan setiap generasi.Kondisi Pendidikan seperti ini tentunya menjadi sebuah catatan besar bagi semua elemen bangsa untuk dapat menemukan formulasi yang tepat dan sesuai karakter anak bangsa. Keadaan berbeda terjadi pada sistem Pendidikan Finlandia yang berhasil menempati posisi pertama sebagai sistem Pendidikan terbaik di dunia. Negara Finlandia menunjukan bahwa Pendidikan yang berlandaskan kesetaraan, tanggung jawab, berbudaya serta kerjasama mampu memberikan hasil yang sangat memuaskan (Putra, 2015). Keberhasilan negara Finlandia tentunya dapat menjadi sebuah rujukan negara Indonesia untuk menjawab pertanyaan bagaimana mengembangkan sistem Pendidikan yang baik.

Kajian kepustakaan adalah metode yang digunakan dalam penelitian ini. Kajian kepustakaan mempelajari berbagai buku referensi serta hasil penelitian sebelumnya yang sejenis yang berguna untuk mendapatkan dan mengumpulkan segala informasi yang relevan dengan masalah yang dikaji (Ulfatin, 2015). Metode pengumpulan data-data serta sumber-sumber yang berhubungan dengan topik penelitian disebut juga kajian kepustakaan. Kajian pustaka bisa diambil dari berbagai sumber yakni majalah, surat kabar, internet, jurnal, buku dokumentasi, 
dan pustaka. Analisis komparasi pendidikan yang dilakukan menggunakan studi kepustakaan dalam menggali topik-topik yang dibahas.

\section{Hasil Dan Pembahasan}

\section{1) Prinsip-prinsip Sistem Pendidikan di Indonesia}

Indonesia telah mengatur semua bentuk aktivitas Pendidikan nasional melalui peraturan perundang-undangan. UUD 1945 dalam alinea ke 4 mengamanahkan agar Pendidikan Indonesia harus mampu memberikan pelayanan terbaik bagi anak bangsa dalam rangka mencerdaskan kehidupan bangsa. Secara terperinci UU No. 20 Tahun 2003 tentang sistem pendidikan nasional menjabarkan secara rapi serta sistematis mengenai sistem Pendidikan Indonesia. Penjabaran mengenai prinsip-prinsip Pendidikan di Indonesia tertuang dalam pasal 4 ayat 1 hingga 6. Dalam penelitian Ristianti (2019) menyebutkan bahwa pendidikan di Indonesia sedang berkembang dari era revolusi industri 4.0 menjadi social education 5.0 didalamnya mengisyaratkan agar penerapan Pendidikan harus dilakukan dengan demokratis serta berkeadilan dan tidak diskriminatif dengan menjunjung tinggi hak asasi manusia, nilai keagamaan, nilai kultural, serta kemajemukan bangsa (Parker \& Raihani, 2011). Selanjutnya UU SISDIKNAS pasal 5 ayat 1 mengamanatkan bahwa semua orang memiliki hak untuk mengenyam pendidikan yang berkualitas baik. Amanah tersebut sepertinya sangat bertentangan dengan amanah undangundang SISDIKNAS pasal 5 ayat 2 hingga 4, yang menyatakan bahwa hanya warga negara yang memiliki kelainan fisik, emosional, mental, intelektual, sosial atau tinggal didaerah terpencil atau terkebelakang, masyarakat adat yang terpencil, serta warga negara yang memiliki potensi kecerdasan dan bakat istimewa berhak memperoleh pendidikan (2003). Sistem pendidikan saat ini seolah-olah merupakan salah satu bentuk dari amanah pasal tersebut, dimana Lembaga Pendidikan nasional begitu antusias untuk melakukan kompetisi. Pemilahan siswa yang memiliki potensi dan kecerdasan diatas rata-rata dengan siswa yang yang memiliki potensi kecerdasan dibawah rata-rata menjadi salah satu bukti yang tersirat.

\section{2) Prinsip-prinsip Sistem Pendidikan di Finlandia}

Faktor yang menjadi kunci dalam pembangunan ekonomi dan peradaban modern di Finlandia adalah pendidikan hal ini disebutkan, secara tegas dalam visinya oleh kementrian Pendidikan Finlandia (Finland, 2015). Kesetaraan pendidikan dan budaya merupakan target strategis yang sangat penting yang ingin diraih oleh pemerintahan Finlandia hal ini tertuang dalam Strategi Kementerian Pendidikan finlandia tahun 2015. Pemerintah Finlandia menjamin kesejahteraan intelektual, fisik dan ekonomi melalui akses pendidikan seluasluasnya bagi warga negaranya. 
Prinsip kompetisi atau persaingan tidak diterima di negara ini, pasalnya publik Finlandia berpegang teguh pada keyakinan prinsip keadilan (equity). Warga negara Finlandia menjunjung tinggi prinsip kesetaraan (equality) dan keadilan (equity) serta bertolak belakang atau tidak menyetujui pengelolaan sekolah berorientasi pasar atau kompetisi (Putra, 2015). Publik atau masyarakat Finlandia mempunyai kekhawatiran atas kesempatan mendapatkan pendidikan. Akses terhadap pendidikan yang sama menjadi prinsip dari pembuatan regulasi di bidang pendidikan. Kebijakan tersebut kemudian mengarah pada suatu keunggulan yang akan memberikan standar pendidikan yang sama terhadap warga negaranya yang diperoleh secara gratis.

Membangun kepercayaan dan tanggung jawab dalam setiap bentuk interaksi dikedepankan oleh publik Finlandia (Putra, 2015). Pengelolaan sistem pendidikan dikembangkan dengan mengedepankan nilai kepercayaan dan tanggungjawab. Guru dan kepala sekolah bersama orang tua dan komunitas yang ada disekolah diyakini mengetahui apa yang harus diberikan dan disiapkan dengan maksimal untuk peserta didik, hal ini ditanamkan oleh otoritas pendidikan di Finlandia dengan menumbuhkan budaya percaya dalam mengelola pendidikan. Budaya percaya juga ditunjang dengan nilai-nilai profesionalisme, percaya diri, kejujuran dan tanggung jawab.

Budaya percaya di Finlandia diperkuat dengan adanya nilaikerjasama dan kolaborasi (Putra, 2015). Upaya untuk menyiapkan perekonomian yang mampu bersaing ditaraf internasional adalah peserta didik dan lembaga pendidikan mengurangi cara belajar dengan konsep bersaing baik antar siswa maupun antar sekolah. Finlandia memiliki pandangan sendiri dalam menghadapi persaingan global, sebaliknya, sekolah harus meningkatkan kolaborasi dan kerjasama. Uraian tersebut menunjukkan adanya perbedaan yang sangat signifikan antar prinsip Pendidikan Finlandia dengan Indonesia. Secara sederhana perbedaan prinsip pendidikan Finlandia dengan Indonesia ditunjukkan pada Tabel 1.

Tabel 1. Perbedaan Prinsip Pendidikan Indonesia dan Finlandia

\begin{tabular}{ll}
\hline \multicolumn{1}{c}{ Indonesia } & \multicolumn{1}{c}{ Finlandia } \\
\hline $\begin{array}{l}\text { Democratic and equty with non-discrimination by } \\
\text { upholding human rights }\end{array}$ & Cooperation and Collaboration \\
$\begin{array}{l}\text { Religious, Cultural, and National Pluralism } \\
\text { Values }\end{array}$ & Equality and Equity \\
Enthusiastic to do the Competition & Trust and Responsibility \\
\hline
\end{tabular}

\section{3) Manajemen Sumber Daya Manusia Pendidikan di Indonesia}

Kualitas pendidikan suatu bangsa mempunyai kaitan yang erat dengan kualitas tenaga pendidik atau guru. Di Indonesia begitu banyak sekolah tinggi keguruan dan universitas yang menyediakan tempat bagi para mahasiswa calon 
guru untuk mendalami keilmuan yang digelutinya. Mengacu pada UU SISDIKNAS pasal 39 ayat 2 Pendidik adalah tenaga profesional yang bertugas sebagai perencana serta pelaksana kegiatan pembelajaran, penilai hasil pembelajaran, pelaksana pembimbingan serta pelatihan, dan melaksanakan penelitian serta pengabdian kepada masyarakat, terutama untuk pendidik pada pendidikan tinggi. Semua perguruan tinggi penghasil lulusan yang nantinya berprofesi guru diharapkan mampu memberikan berbagai pelatihan berkaitan kompetensi yang telah disebutkan. Selanjutnya pada pasal 40 ayat 2 poin a bahwa guru dituntut untuk menjadi seorang tenaga pendidik yang inovatif dan kreatif. Untuk menunjang tuntutan ini, hampir seluruh perguruan tinggi di Indonesia mewajibkan mahasiswa keguruannya untuk melaksanakan kegiatan lapangan, dalam hal ini melakukan simulasi pembelajaran. Selain itu kegiatan penelitian diwajibkan pada mahasiswa calon guru yang bertujuan untuk meningkatkan kemampuannya dalam memecahkan masalah.

Guru di Indonesia harus memiliki kualifikasi akademik dan kompetensi yakni mampu mengartikulasi dan mencapai tujuan pendidikan, sehat jasmani serta rohani, dan mempunyai kompetensi sebagai agen pembelajaran (Blazar \& Kraft, 2017), hal ini telah diatur oleh BSNP (Badan Standar Nasional Pendidika). PERMENDIKNAS No 16 tahun 2007 menjelaskan standar kompetensi tenaga pendidik mulai dari tingkatan PAUD hingga jenjang SMA sekurang-kurangnya adalah diploma 4 dalam bidangnya. Sehingga dapat disimpulkan bahwa proses Pendidikan hingga standar nasional seorang tenaga pendidik telah ditata secara rapi (2007).

Rekrutmen guru di sekolah, kepala sekolah memiliki peranan penting dalam perekrutannya. Guru yang baik dihasilkan dari proses rekrutmen yang baik.Permasalahan yang terjadi saat ini adalah banyaknya proses rekrutmen yang tidak sesuai aturan yang ada contohnya adalah banyaknya guru yang mengajar atau diterima disekolah yang tidak sesuai dengan bidang keilmuannya yang tentu saja akan memengaruhi kegiatan pendidikan itu sendiri. Hal ini tentunya bertentangan dengan peraturan yang mengatur standar kualifikasi akademik dan kompetensi guru yang dijelaskan diatas.

Peraturan Menteri Pendidikan dan Kebudayaan Republik Indonesia No. 14 tahun 2018 mengatur tentang standar lembaga pendidikan dalam menerima siswa baru. Pasal 5-8 menyatakan bahwa tingkat TK harus memiliki kualifikasi usia sekurang-kurangnya 4 tahun, SD minimal 6 tahun tetapi menggunakan rekomendasi tertulis dari psikolog profesional bagi calon peserta didik yang mempunyai kecerdasan istimewa/bakat istimewa serta kesiapan psikis diperbolehkan mengikuti pendidikan di tingkat SD dengan usia 5 tahun 6 bulan, Jenjang smp kelas 7 berusia paling tinggi 15 tahun dan untuk jenjang SMA/SMK kelas 10 berusia paling tinggi 21 tahun. Peraturan ini pun menjadi acuan untuk setiap Lembaga Pendidikan untuk tidak memaksakan anak diusia 
tertentu mengenyam Pendidikan (Notoatmojo, 2011).

\section{4) Manajemen Sumber Daya Manusia Pendidikan di Finlandia}

Guru menjadi aktor pelaksana utama dalam menerapkan berbagai macam strategi, metode maupun regulasi yang telah ditentukan kurikulum nasional. Guru selalu menjadi panutan utama para peserta didik disekolah. Keseriusan Finlandia terhadap kualitas guru patut diteladani. Finlandia mampu menjadikan guru dinegaranya menjadi sosok yang sangat dihormati dikalangan masyarakat pada umumnya. Pencapaian ini tentunya tidak diperoleh dengan mudah tanpa melalui usaha-usaha yang cukup keras. Kualifikasi akademik bagi guru yang paling dasar adalah master, untuk menjadi guru mahasiswa akan melewati tiga tahap untuk memastikannya bisa menjadi guru profesional atau tidak. Tahap pertama, mahasiswa akan melaksanakan ujian kompetensi yang berkaitan dengan pemecahan masalah Pendidikan. Tahap kedua, mahasiswa akan melakukan tahap wawancara serta melakukan sebuah simulasi pemecahan masalah. Kerjasama, komunikasi, serta kreativitas menjadi komponen utama dalam penilaian. Tahap ketiga, merupakan penentu apakah seorang bisa diterima menjadi guru atau tidak. Seorang mahasiswa akan dinilai dari semua aspek pendidikannya termasuk resume hasil uji pada tahap sebelumnya.

Pengembangan potensi profesi guru dilakukan melalui banyak metode salah satunya adalah mewajibkan para calon guru untuk melaksanakan pembelajaran ditingkat universitas melalui penelitian dan pelatihan pengembangan profesi.Kualifikasi yang diuraikan tersebut dapat dibayangkan betapa berkualitasnya para guru di Finlandia. Hasil penelitian yang berupa tesis dapat dijadikan dasar seorang guru dalam mengelola peserta didiknya (Goodill, 2017). Upaya guru untuk mengembangkan kemampuan selalu didukung penuh oleh pemerintahannya. Penelitian dan pelatihan ini dinilai mampu mengarahkan para guru untuk mampu mengenali kekurangan serta menemukan solusi atas kekurangannya sendiri sehingga dapat memberikan Pendidikan yang baik bagi peserta didiknya. Guru di Finlandia selalu diarahkan untuk memiliki kompetensi religious. Ini terbukti dengan konsep lain dari Pendidikan guru yaitu melalui pendalaman iman yang dididik oleh pemimpin agamanya masing (Goodill, 2017). Pemilihan peserta didik tidak melalui kualifikasi yang sangat rumit. Salah satu persyaratan utamanya adalah peserta didik harus mencapai usia 7 tahun yang dinilai telah cukup mampu untuk melakukan aktivitas fisik dan otak yang lebih. Struktur usia dan jenjang pendidikan di finlandia bisa dilihat pada Gambar 1, secara sederhana perbedaan SDM pendidikan Indonesia dan Finlandia ditunjukkan pada Tabel 2. 
Tabel 2. Perbedaan SDM Pendidikan Indonesia dan Finlandia

\begin{tabular}{ll}
\hline \multicolumn{1}{c}{ Indonesia } & \multicolumn{1}{c}{ Finlandia } \\
\hline Kualifikasi Guru minimal D4 & Kualifikasi guru minimal S2 (Master) \\
Kualifikasi peserta didik memasuki & Kualifikasi peserta didik memasuki \\
pendidikan dasar minimal 6 tahun (5,5 & pendidikan dasar minimal 7 tahun \\
tahun disertai rekomendasi tertulis dari & \\
psikolog profesional) & \\
\hline
\end{tabular}

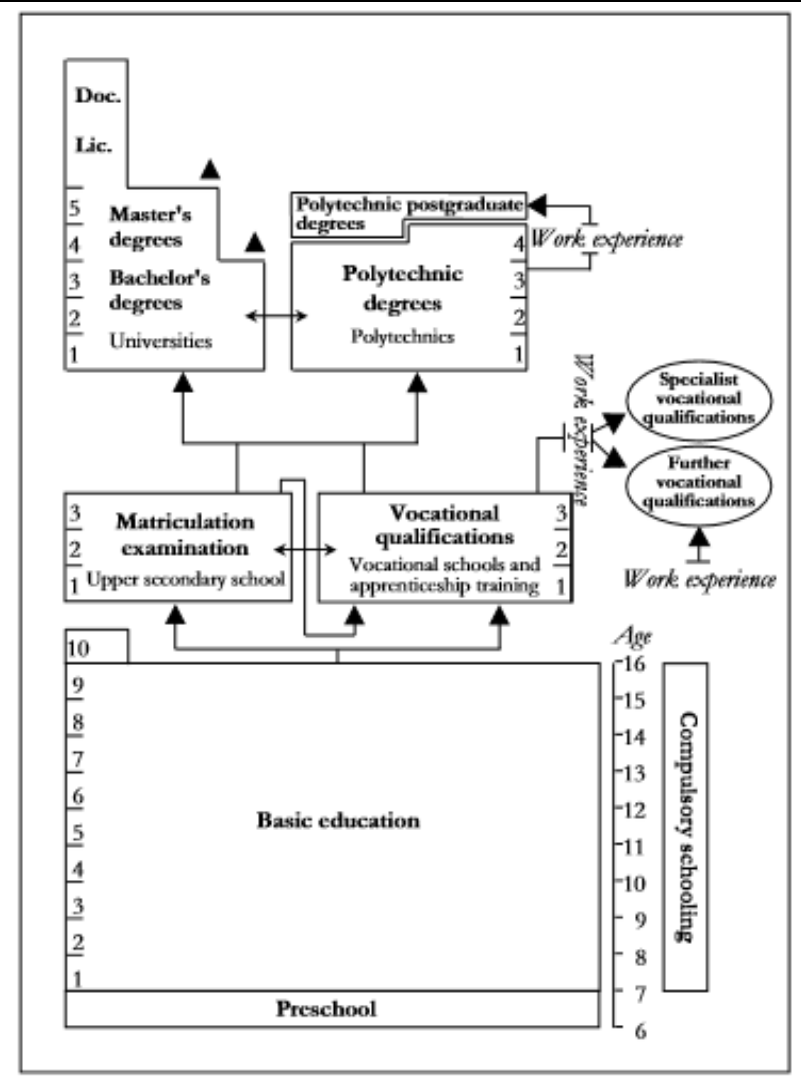

Gambar 1. Education System in Finnish (Finnish National Agency For Education, 2018)

\section{5) Kurikulum Pendidikan Dasar di Indonesia dan Finlandia}

Secara umum pemerintah Finlandia sangat bertanggung jawab dalam penyelenggaraan Pendidikan di negaranya. Peserta didik akan diberikan kenyamanan serta fasilitas pendukung dimulai dari Pre-primary sampai pada Pendidikan tinggi. Kurikulum Pre-primary bertujuan untuk menyiapkan para calon peserta didik untuk mengenyam Pendidikan di tingkat Pendidikan dasar. Pada tahap ini Pendidikan ditekankan pada usaha membangkitkan keterampilan anak melalui kegiatan belajar sambil bermain. 
Finlandia menetapkan usia minimal peserta didik untuk memasuki Pendidikan dasar adalah saat memasuki 7 tahun. Finlandia memiliki Badan yang bernama The National Board of Education. Badan ini memiliki tugas untuk menyusun kurikulum inti secara nasional (Finnish National Agency For Education, 2018). Kurikulum di Finlandia disusun bertujuan untuk menghadirkan suatu standar isi dan berfungsi sebagai pemandu untuk lembaga pendidikan. Mata pelajaran yang diajarkan disesuaikan berdasarkan kebutuhan peserta didik yang dilakukan oleh pemerintah lokal, sekolah dan bahkan orang tua dapat ikut serta menyusun kuruikulum pendidikan dan tujuannya.

Pendidikan di Finlandia menggunakan sistem kurikulum struktur tunggal. Pendidikan dasar ditempuh selama 9 tahun. Pendidikan 6 tahun pertama akan dididik oleh guru yang sama dalam melaksanakan pembelajaran (Anggoro, 2017). Sistem ini dilakukan dengan tujuan agar pembelajaran dapat difokuskan untuk mengasah keterampilan dan menggali potensi setiap peserta didik. Memasuki tiga tahun terakhir masa pembelajaran peserta didik akan dididik oleh guru matapelajaran untuk memperkenalkan ilmu pengetahuan dasar seperti matematika, sejarah, ilmu sosial, ilmu agama, Bahasa inggris , Bahasa italia, Bahasa jerman dan ilmu pengetahuan dasar lainya. Bahasa internasional selalu digunakan dalam pelaksanaan pembelajaran yang bertujuan untuk membiasakan para siswa. Salah satu perhatian utama mereka yakni pembentukan karakter peserta didik. Kurikulum di Indonesia juga memuat beberapa mata pelajaran utama yakni bahasa, pendidikan agama, pendidikan kewarnegaraan, ilmu pengetahuan sosial,matematika, ilmu pengetahuan alam, pendidikan jasmani dan olah raga, keterampilan atau kejuruan, seni dan budaya, serta muatan lokal. Perbedaan yang sangat terlihat dari kedua kurikulum tersebut adalah bahwa Finlandia lebih banyak menekankan penguasaan bahasa dan sastra termasuk bahasa asing pada peserta didiknya.

Pemerintah Finlandia tidak menerapkan sistem tinggal kelas seperti yang ada di indonesia. Kesetaraan dan menjaga mental para peserta didik menjadi alasan utama diberlakukannya sistem ini. Selain itu sistem penilaian terstruktur dalam setiap pertemuan, pembagian raport, dan pemberian beban tugas kepada peserta didik tidak termasuk dalam kurikulum Finlandia. Sebuah pencapaian pembelajaran akan diketahui mealui kegiatan matrikulasi yang diadakan sebelum memasuki perguruan tinggi. Siswa membuat sendiri kompetensi yang hendak dicapai dalam pembelajarandan dibantu orang tuanya. Kegiatan pembelajaran mengedepankan proses yang baik dan bertahap. Untuk meningkatkan kemampuan peserta didiknya dalam mengenali lingkungan sekitar, Pendidikan Finlandia selalu memberikan pemahaman terhadap teori melalui kegiatan pemecahan masalah terutama dalam ilmu sains (Kasihadi, 2016). Membandingkan sistem pendidikan Indonesia, tentu ini hal ini cukup berbeda. Di Indonesia terlihat begitu kental adanya rangking dan tidak naik kelas. Selain 
aspek tersebut, terlihat perbedaan yang paling mencolok dimana hari efektif sekolah di Finlandia sebanyak 190 hari/tahun sedangkan hari efektif sekolah di Indonesia mencapai 230 hari/tahun. Suasana kegiatan belajar mengajar di Finlandia sangat fleksibel dan amat nyaman yang dilaksanakan dengan mengusung konsep mengembangkan keterampilan melalui proses pembelajaran yang baik. Secara singkat dapat dipetakan perbedaan sistem Pendidikan dasar Finlandia dengan Indonesia pada Tabel 3.

Tabel 3. Perbedaan Sistem Pendidikan dasar Indonesia dan Finlandia

\begin{tabular}{ll}
\hline \multicolumn{1}{c}{ Indonesia } & \multicolumn{1}{c}{ Finlandia } \\
\hline Sistem Pendidikan diwarnai banyak kompetisi & Mengedepankan prinsip kesetaraan \\
Ada sistem tinggal kelas dan perangkingan & Tidak ada sistem tinggal kelas dan \\
& perangkingan \\
Beban belajar setiap minggu $+/-40$ jam & Jam pelajaran 30 jam/minggu \\
Pembelajaran lebih banyak dikelas & Mengedepankan metode problem solving \\
Pemberian tugas hampir menjadi agenda rutin & Tidak membebani peserta didik dengan tugas \\
setiap tatap muka & yang banyak \\
Kualifikasi Guru minimal D4 & Kualifikasi guru minimal S2 (Master) \\
Kualifikasi peserta didik memasuki pendidikan & Kualifikasi peserta didik memasuki pendidikan \\
dasar minimal 6 tahun $(5,5$ tahun disertai & dasar minimal 7 tahun \\
rekomendasi tertulis dari psikolog profesional) & \\
\hline
\end{tabular}

6) Sarana dan Prasarana Pendidikan Indonesia dan Finlandia

Kualitas fisik bangunan sekolah tidak bisa digambarkan sebagai kualitas pendidikan, Finlandia telah membuktikannya. Hal ini dikarenakan siswa tidak belajar dikelas-kelas, mereka boleh belajar disudut-sudut ruangan dengan mempelajari materi pelajaran apapun dalam arti penggunaan ruangan dilakukan secara bebas. Guru menyarankan siswa bermain jika siswa telah bosan atau penat dalam belajar dikelas. Hampir seluruhnya proses belajar mengajar di diadakan didalam kelas, siswa duduk manis dibangkunya dan pendidik berceramah didepan kelas.

Fasilitas bimbingan konseling bagi siswa diwajibkan oleh pemerintah Finlandia. Perhatian luar biasa ditujukan kepada siswa yang memiliki gangguan psikologis dan lemah mental. Peserta didik yang memiliki kebutuhan khusus di Indonesia sebagian besar tidak bersekolah di sekolah umum, melainkan bersekolah di Sekolah Luar Biasa (SLB).

Siswa di Finlandia mendapatkan makan siang secara gratis dengan makanan yang bergizi tinggi dari pemerintah Finlandia hal ini karena kecerdasan siswa dipercaya dipengaruhi asupan gizi yang baik. Lembaga pendidikan di Indonesia mayoritas tidak memberikan fasilitas itu secara gratis. Bus sekolah antar jemput bagi siswa juga disediakan secara cuma-cuma oleh pemerintah Finlandia. Buku-buku teks pembelajaran juga sudah disediakan oleh sekolah 
ditunjang dengan jaringan internet yang memadai diperpustakaan sekolah, sedangkan yang terjadi di Indonesia walaupun dalam menjalankan kegiatan operasionalnya pemerintah menganggarkan sejumlah bantuan salah satunya dana BOS tetapi dalam pelaksanaan nya masih banyak penyimpangan-penyimpangan yang terjadi seperti keterlambatan kedatangan buku-buku yang disediakan oleh pemerintah disekolah sehingga kegiatan belajar peserta didik terhambat. Perpustakaan di Indonesia mayoritas juga belum banyak yang dilengkapi fasilitas WIFI atau akses internet bahkan di daerah-daerah tertinggal juga belum bisa berfungsi dengan baik.

Generasi penerus bangsa di Finlandia sangat diperhatikan oleh pemerintahannya, berbeda dengan Indonesia (Kasihadi, 2016), di Indonesia sekolah-sekolah yang berkualitas baik hanya bisa dinimati oleh anak-anak yang mempunyai orang tua berpenghasilan tinggi . Sekolah yang memiliki kualitas yang baik identik dengan biaya pendidikan yang tinggi, sehingga akses untuk menempuh pendidikan yang berkualitas bagi masyarakat yang berpenghasilan rendah dinilai cukup memberatkan para orang tua (Widodo, 2016). Akses mendapatkan pendidikan yang berkualitas inilah juga yang semakin menimbulkan kesenjangan diantara masyarakat.

\section{7) Pendidikan Internasional}

Negara finlandia sangat serius dalam masalah peningkatan mutupendidikan. Hubungan internasional menjadi salah satu cara dalam mewujudkan tujuan tersebut. Peningkatan mutu melalui hubungan internasional dapat dilakukan melalui beberapa cara diantaranya pelatihan keterampilan bertaraf internasional dengan menghadirkan narasumber dari luar negeri, pertukaran pelajar antar negara, dan sebagainya. Negara Indonesia juga sudah melakukan hubungan internasional seperti yang dilakukan finlandia pada jenjang pendidikan tinggi, seyogyanya hal ini juga diberlakukan pada semua jenis pendidikan di Indonesia secara menyeluruh.

Negara Finlandia ikut aktif dalam membangun hubungan inernasional mereka dalam dunia pendidikan dengan negara-negara eropa dimulai pada tahun 1995 melalui program internasionalisasi universitas-universitas di Finlandia. Pendidikan tinggi Finlandia memberikan kompetensi untuk bekerja di lingkungan operasi internasional. Pengalaman internasional dan koneksi staf lembaga pendidikan tinggi meningkatkan kualitas penelitian dan pendidikan dan mendukung internasionalisasi siswa. Institusi pendidikan tinggi menawarkan pendidikan berkualitas tinggi yang berfokus pada bidang keahlian mereka, yang diberikan dalam bahasa asing (Ministry of Education Finland, 2015). Selanjutnya, lembaga pendidikan tinggi secara aktif memanfaatkan peluang kerjasama internasional, khususnya, di negara-negara Uni Eropa dan Nordik. Pendidikan tinggi di indonesia banyak melakukan kerjasama internasional. Hubungan 
internasional yang dilakukan berbentuk pertukaran pelajar antar universitas, dan masih banyak lagi.

\section{8) Sistem Inovasi Nasional Negara Finlandia}

Kegiatan penelitian dan pengembangan terhadap sistem pendidikan dan inovasi yang muktakhir berdampak padapeningkatan kualitas pendidikan suatu negara. Salah satu sektor yang krusial dalam pengembangan sistem pendidikan finlandia adalah kegiatan peneliti. Pemerintah finlandia memberikan kebebasan bagi para peneliti untuk menemukan dan mengembangkan berbagai macam bentuk inovasi pendidikan. Ada beberapa elemen sentral yang dibutuhkan pemerintah finlandia dalam sistem inovasi teknologi negara finlandia yang dapat disederhanakan melalui gambar 2 .

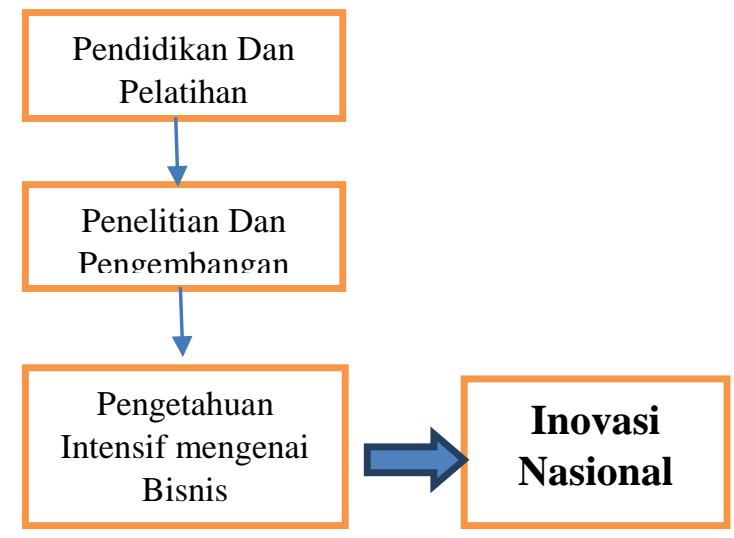

Gambar 2 Elemen Sistem Inovasi Nasional Finlandia.

Sistem inovasi nasional finlandia erat kaitannya dengan pendidikan dan pelatihan sebagai ilmu dasar seorang peneliti dalam melakukan riset. Seorang peneliti akan mempelajari kebutuhan apa saja yang sedang menjadi isu utama dalampermasalahan nasional. Upaya ini akan berdampak pada keputusan serta sasaran utama dalam melakukan riset. Ilmu pengetahuan dipandang sebagai konsep dasar untuk mengembangkan karya-karya yang bermanfaat dalam kehidupan sehari-hari. Sistem terdiri dari input, proses, output, serta umpan balik. Kegiatan riset adalah salah satu usaha untuk mengubah kualitas input sehingga memberi dampak pada perubahan-perubahan dimasa yang akan datang (output).

Untuk menjamin mutu pelaksanaan riset inovasi nasional serta dapat memberikan dampak yang baik bagi perkembangan sistem pendidikan dinegaranya, Finlandia membutuhkan aktor strategis yang ikut andil dalam kegiatan ini diantaranya adalah industri, universitas, lembaga penelitian, dan pemerintah. Keterkaitan diantara setiap sektor penting ini telah memberikan dampak yang baik dalam pengembangan sistem pendidikan serta kemajuan negara Finlandia (Uotila, Harmaakorpi, \& Hermans, 2013). Universitas dan lembaga penelitian lainya yang menyediakan tenaga riset sangat mebutuhkan 
andil pemerintah sebagai pemberi ijin maupun penentu kebijakan. Begitupula dengan industri yang dapat berperan sebagai lokasi riset maupun pelaksana kebijakan baru pemerintah sebagai hasil penemuan riset. Secara sederhana dapat digambarkan keterkaitan antara aktor dalam program inovasi nasional Finlandia sebagai berikut.

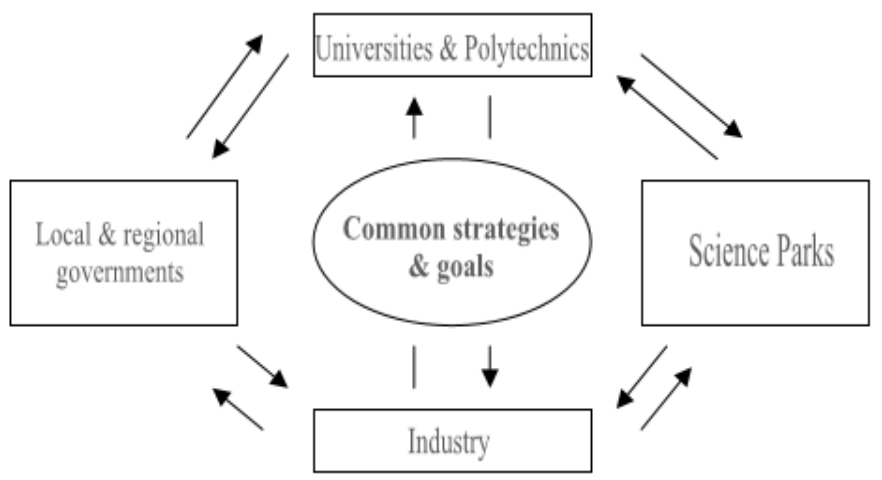

Gambar 3 Major Actors In the Centers of Expertise Program

\section{9) Resistansi Finlandia terhadap Global Educational Reform Movement}

Globalisasi menyebabkan perkembangan dan membawa beragam substansi ke seluruh dunia. Global Educational Reform Movement (GERM) atau gerakan reformasi pendidikan merupakan fenomena global yang sampai saat ini masih terjadi di banyak negara. Pada beberapa dekade terakhir (P Sahlberg, 2009) menyatakan GERM mentransformasi sistem pendidikan di banyak negara. Secara singkat dapat dipetakan perbedaan nilai-nilai pendidikan GERM dan Finlandia pada Tabel 4.

Tabel 4. Perbedaan Nilai-Nilai Pendidikan GERM dan Finlandia

\begin{tabular}{|c|c|}
\hline GERM & Finlandia \\
\hline Competition & Cooperation and Collaboration \\
\hline Freedom of Choice & Equality and Equity \\
\hline Accountability & Trust and Responsibility \\
\hline $\begin{array}{l}\text { Dasar bagi keb } \\
\text { peningkatan mutu pendic } \\
\text { berpijak pada nilai-nila } \\
\text { sekolah yang akan dip } \\
\text { pendidikan mulai dari gu } \\
\text { telah ditentukan. Sisi yan } \\
\text { pendidikan berdasarkan }\end{array}$ & $\begin{array}{l}\text { an berdasarkan nilai GERM yakni } \\
\text { tput maupun dari segi pengelolaannya } \\
\text { syarakat bebas menentukan pilihan } \\
\text { pelaksanaan yang berkaitan dengan } \\
\text { ilitas harus sesuai dengan standar yang } \\
\text { an di negara Finlandia, pengembangan } \\
\text { araan dan keadilan, kepercavaan dan }\end{array}$ \\
\hline
\end{tabular}


tanggung jawab menjadi mekanisme pengelolaan pendidikan di Finlandia, dan nilai kerjasama dan kolaborasi ditekankan dalam pengelolaan pendidikan.

Penelitian mengenai pengaruh diselenggarakannya kebijakan pilihan sekolah serta kompetisi terhadap kualitas pembelajaran telah dilakukan oleh para peneliti di banyak negara. Rendahnya hubungan pilihan sekolah serta kompetisi terhadap kualitas pembelajaran ditunjukkan oleh penelitian yang dilakukan oleh Ladd dan Fiske (dalam Gagnidze and Maglakelidze 2017) di Selandia Baru. Hasil penelitian tersebut menunjukkan dampak negatif pilihan sekolah serta kompetisi terhadap kualitas pembelajaran. Artinya, kompetisi malah menurunkan kualitas pembelajaran.

Penelitian yang dilakukan oleh Lauen dan Gaddis (2016) penentuan akuntabilitas melalui tes serta standarisasi memiliki dampak yang rendah terhadap prestasi siswa. Hasil penelitian tersebut menunjukkan, pertama bagi siswa, pemberlakuan tes serta standarisasi dianggap menurunkan kekritisan berfikir. Kedua, bagi guru, akuntabilitas serta standarisasi membuat anggapan bahwa guru tidak dapat kreatif serta independen dalam mengatur pembelajaran di kelas. Guru banyak yang menganggap tidak lagi dihargai karena harus diperiksa secara berkelanjutan. Guru maupun sekolah dipaksa menjalankan standar atau regulasi yang ditetapkan oleh pemerintah akibat adanya sistem akuntabilitas.

Implikasi nilai kesetaraan dan keadilan adalah "education for all" artinya setiap warga negara berhak mendapatkan akses pendidikan yang bermutu tanpa melihat status sosial atau atribut yang menempel pada tiap-tiap orang (Sahlberg 2011). Sebaliknya, implikasi nilai yang didasarkan dalam GERM menciptakan kebijakan seperti privatisasi sekolah yang menimbulkan kesenjangan (Putra, 2015). Output kebijakan yang didasarkan pada nilai GERM tersebut bertentangan dengan nilai-nilai kesetaraan serta keadilan negara Finlandia. Implementasi kebijakan yang berdasar pada nilai GERM yakni akuntabilitas serta standarisasi mempunyai dampak yang tidak baik pada kreatifitas berpikir dan independensi pendidik dengan adanya sistem penilaian atau inspeksi yang dilakukan.

\section{Penutup}

Kesimpulan yang dapat diambil yakni nilai-nilai kesetaraan dan keadilan, nilai-nilai kepercayaan dan tanggungjawab, dan nilai-nilai kerjasama dan kolaborasi dikembangkan dalam pengelolaan pendidikan di Finlandia. Hal ini agaknya bertentangan dengan pelaksanaan pendidikan yang ada di indonesia yakni yang mengutamakan persaingan, adanya tinggal kelas dalam sistem pendidikan nya. Negara Finlandia tidak menerapkan sistem tinggal kelas perangkingan dengan jam pelajaran 30 jam perminggu, mengedepankan metode problem solving, tidak membebani peserta didik dengan banyak tugas dan 
kualifikasi guru minimal S2 dengan kualifikasi peserta didik mengikuti pendidikan dasar minimal berusia 7 tahun, sedangkan indonesia menerapkan sistem tinggal kelas dan perangkingan, beban belajar setiap minggu 40 jam/minggu, pembelajaran lebih banyak didalam kelas, pemberian hampir menjadi agenda rutin setiap tatap muka, dan kualifikasi guru minimal D4 dengan Kualifikasi peserta didik memasuki pendidikan dasar minimal 6 tahun (5,5 tahun disertai rekomendasi tertulis dari psikolog profesional).

Berdasarkan kesimpulan yang dijabarkan sebelumnya, maka dirumuskan saran yakni pemerintah hendaknya merumuskan kebijakan yang dapat sistem pendidikan negara lain yang telah terbukti berhasil dalam peningkatan pendidikan di negaranya, untuk peneliti selanjutnya agar merancang sebuah analisis komparatif sistem pendidikan yang ada pada negara Indonesia, negara berkembang, dan negara maju guna mencari formula sistem pendidikan yang paling tepat dengan karakteristik serta tantangan dan peluang pendidikan di Indonesia.

\section{Daftar Pustaka}

Anggoro, S. (2017). Keberhasilan Pendidikan Finlandia.

Blazar, D., \& Kraft, M. (2017). Teacher and Teaching Effects on Students' Attitudes and Behaviors. Educational Evaluation and Policy Analysis, 39(1), 146-170. https://doi.org/DOI: 10.3102/0162373716670260

Charron, N., Ph, D., Givens, T., Luedtke, A., Arregui, J., Creighton, M., ... Connell, K. O. (2013). Human Development Report 2015 Work for Human Development. Public Health, 27(6), 1-8. https://doi.org/10.1177/0956247815583253

Finland, M. of E. (2015). Ministry of Education 2015.

Finnish National Agency For Education. (2018). Education System: Equal Opportunities to High Quality Education.

Gagnidze, A., \& Maglakelidze, S. (2017). Competition on the Georgia Education Marketplace. International Education Studies, 10(6), 10-22.

Goodill, C. . (2017). An Analysis of the Educational System In Finland and the United States: A Case Study.

Kasihadi, R. . (2016). Optimalisasi Prestasi Peserta Didik Melalui Sistem Pendidikan yang Humanis: Suatu Perbandingan dengan Negara Maju. Jurnal Widyatama, 20(2), 145-151.

Lauen, D, L., \& Gaddis, S. . (2016). Accountability Pressure, Academic Standards, and Educational Triage. Educatinal Evaluation and Policy Analysis, $38(1), 127-147$.

Liputan6.Com. (2014). Pendidikan di Finlandia Maju Berkat Ki Hajar Dewantara.

Notoatmojo, S. (2011). Pengembangan Sumber Daya Manusia. Jurnal LPPM 
Bidang EkoSosBudKum, 2(1), 124.

OECD. (2015). Country Note Results of PISA 2015: Indonesia.

Parker, L., \& Raihani, R. (2011). Democratizing Indonesia through Education ? Community Participation in Islamic Schooling. Educational Management Administration \& Leadership, 39(6), 712-732. https://doi.org/10.1177/1741143211416389

Peraturan Menteri Pendidikan dan Kebudayaan Republik Indonesia No. 14 Tabun 2018 Tentang PPDB Pada TK, SD, SMP, SMA, SMK, Atau Bentuk Lain yang Sederajat. (2018). Jakarta: Kementerian Pendidikan dan Kebudayaan.

Peraturan Menteri Pendidikan Nasional No.16 Tabun 2007 Tentang standar kualifikasi akademik dan kompetensi guru. (2007). Jakarta: Kementerian Pendidikan Nasional.

Pfeffer, F. T. (2015). Equality and Quality in Education a Comparative Study of 19 Countries. Social Science Research, 51(1), 350-368. https://doi.org/10.1016/j.ssresearch.2014.09.004

Putra, K. . (2015). Resistansi Finlandia terhadap Global Educational Reform. Jurnal Analisis Hubungan Internasional, 4(1), 1393-1421.

Reynolds, D., Caldwell, B. J., Cruz, R. M., Miao, Z., Murillo, J., Mugendawala, H., ... Ramon, M. R. R. (2015). Comparative educational research. In The Routledge International Handbook of Educational Effectiveness and Improvement: Research, Policy, and Practice. https://doi.org/10.4324/9781315679488

Sahlberg, P. (2009). Education Reform For Rising Economic Competitiveness. International Organizations Research Journal, 4(1), 15-33.

Sahlberg, Pasi. (2011). Paradoxes of Educational Improvement: The Finnish Experience. Scottish Educational Review, 43(1), 3-23.

Sarica, G. N., \& Cavus, N. (2009). New trends in 21st Century English learning. Procedia - Social and Behavioral Sciences, 1(1), 439-445. https://doi.org/10.1016/j.sbspro.2009.01.079

Ulfatin, N. (2015). Metode Penelitian Kualitatif di Bidang Pendidikan: Teori dan Aplikasinya. Malang: Media Nusa Creative.

Uotila, T., Harmaakorpi, V., \& Hermans, R. (2013). Finnish Mosaic of Regional Innovation System Assesment of Thematical Regional Inovation Platforms Based on Related Variety. European Planning Studies, 20(10), 1583-1602.

UU RI NO.20 Tabun 2003 Tentang Sistem Pendidikan Nasional. (2003). Jakarta: Kreasi.

Widodo, H. (2016). Potret Pendidikan di Indonesia dan Kesiapannya dalam Menghadapi Masyarakat Ekonomi Asia (MEA). Cendekia: Journal of Education and Society, 293. https://doi.org/10.21154/cendekia.v13i2.250 